\title{
The Late SIR WILLIAM PALIN ELDERTON K.B.E., Ph.D.(OsLo)
}

By the death on 6th April 1962 of Sir William Palin Elderton, the Faculty lost an eminent member who will be sadly missed by actuaries all over the world and by others with whom his wide interests brought him into contact. He was the second of the only two actuaries ever to have been honoured by the presentation of a gold medal jointly by the Institute and Faculty to mark outstanding services to the actuarial profession. The other was the late G. J. Lidstone and it is notable that neither was a Fellow of the Faculty by examination but both were distinguished Fellows of the Institute who were elected to membership, Lidstone after coming to Scotland as Manager and Aotuary of the Soottish Widows' Fund, and Elderton, who always had his headquarters in London, in 1931.

The proposal first made to him was that he should be elected an Honorary Fellow but he was quite definite in his view that he would value even more the honour of ordinary Fellowship with all the privileges that would carry and subject to all the obligations of membership.

It was typical of Elderton that he should wish to be treated as an ordinary Fellow of the Faculty and that after age 70, when subscriptions normally cease, he should express his desire to continue payments as a donation to the Faculty ; moreover that, shortly before his death, he should make a generous gift of $£ 200$ to be used by the Faculty in any way the Council might decide. He greatly valued his association with the Faculty which must count itself fortunate in having had him as a Fellow for over 30 years. He was a generous friend who had the Faculty's interests much at heart.

At the time of his election as a Fellow he delivered to the Faculty a lecture on William Morgan, F.R.S., described by the President, Steuart Macnaghten, as " the first actuary in the sense of the term used by us today". It was a delightful essay in the biographical field which was one of his many interests. Some years later he submitted a paper on "options" and often attended meetings of the Faculty and contributed to discussions, generally about the continuous mortality investigation.

As far as the Faculty is concerned, Elderton will be remembered mainly in connection with the joint investigation by the Institute and Faculty of the offices' mortality experience among assured lives 
and annuitants, as the actuary responsible with Colonel H. J. P. Oakley for the $a^{(n)}$ and $a^{(m)}$ tables published in 1924, which for the first time in a published table for life office annuitants, made some allowance for probable future improvement in mortality and as the prime mover in the adoption of the census method of collection and tabulation of data for the continuous investigation of the experience of assured lives and annuitants of the life offices which has been in operation since 1924. It was a great tribute that in 1951 the Joint Committee concerned with the preparation of new tables for annuitants decided that the $a^{(n)}$ and $a^{(m)}$ form was the best to adopt for practical purposes.

There is no need to dilate on his outstanding work for the actuarial profession or on his distinguished services in other spheres which brought him many honours; these have been fully covered in the admirable obituary notices published elsewhere in, for example, The Times, J.I.A., J.R.S.S., and also in Biometrika, which was only to be expected in view of his long and close association with the late Prof. Karl Pearson and with that publication from its early days.

He was a pioneer in bringing modern statistical methods before the actuarial profession and his many reviews of statistical works, in J.I.A., make valuable reading and throw much light on his own views. He never tired of urging the need for careful arithmetical analysis of statistics before the application of mathematical methods. Perhaps the last two sentences of the report of his contribution to the discussion on the "Messurement of Morbidity", J.I.A., Vol. 83, p. 260, give as good an example as any of his view. "He suggested that the young " actuary or statistician who enjoyed applying modern mathematical "statistical methods should be warned not to do so until he had first " spent many tedious hours satisfying himself that the statistics were "above suspicion. Poor or inaccurate or faulty statistics could not be "made better by mathematics."

Elderton's deep interest in the younger members of the profession and his constant desire to help them have been emphasised elsewhere and there must be few who have not had personal experience of this. The writer, as a young actuary, had the inspiring experience of meeting him first in the 1920's and since then the good fortune to work with him over many years on mortality investigation. It was a wonderful experience which will never be forgotten for, in addition to its inestimable value in the professional field, it has left delightful memories of a personal friendship, of walking with him in his beloved Chiltern country and of meetings with the charming Lady Elderton to whom all actuaries extend their warm sympathy, feeling thankful 
that she has the consolation that he lived to the ripe age of 84 and was active to the last.

All actuaries and many others will be conscious of a vacant place but all will feel grateful for having had him among them. It is seldom given to any man to see so many of his ideas adopted by his profession in his own lifetime. Those who had the good fortune to work with him will never forget the inspiration of his example, his human understanding, his kindness and encouragement, friendliness and helpfulness, his commonsense approach to problems and his hatred of humbug or pretentiousness and always, his sense of fun and delightful ready laugh. How often was a difficult situation overcome by a humorous remark and that characteristic laugh! All will remember too, his brevity and conciseness of expression which may have owed a lot to his habit of writing so many letters and memoranda in his own hand in beautiful, neat and legible handwriting that was the envy of many and appropriate from one who was a gifted artist in black and white and water colour. His passion for compression was mentioned in his written reply to the discussion on his last paper to the Institute delivered 50 years after the first one-a great record fitting for a great actuary.

R. LL, G. 